\title{
38. STRONTIUM- AND LEAD-ISOTOPE COMPOSITION OF SOME BASALTS FROM DEEP SEA DRILLING PROJECT HOLE 504B, COSTA RICA RIFT, LEGS 69 AND 701
}

\author{
T. J. Barrett, ${ }^{2}$ Department of Geology and Mineralogy, Oxford University, Oxford OX1 3PR, United Kingdom
}

\begin{abstract}
Seventeen whole-rock samples, generally taken at 25 - to 50 -meter intervals from 5 to 560 meters sub-basement in Deep Sea Drilling Project Hole 504B, were analyzed for ${ }^{87} \mathrm{Sr} /{ }^{86} \mathrm{Sr}$ ratios, and rubidium and strontium concentrations. Ten of these samples also were analyzed for $\mathrm{Pb}$-isotope composition. Strontium-isotope ratios for eight samples from the upper 260 meters of the hole range from 0.70287 to 0.70377 , with a mean of 0.70320 . In the interval 330 to 560 meters, five samples have a restricted range of 0.70259 to 0.70279 , with a mean of 0.70266 , almost identical to the average value of fresh mid-ocean-ridge basalts. In the interval 260 to 330 meters, approximately intermediate strontium-isotope ratios are found.

The higher ${ }^{87} \mathrm{Sr} /{ }^{86} \mathrm{Sr}$ ratios in the upper part of the hole can be interpreted in terms of strontium-isotope alteration during basalt-sea-water interaction. Relative to average fresh mid-ocean ridge basalts, the upper 260 meters of basalts are enriched by an average of about $9 \%$ in sea-water strontium $\left({ }^{87} \mathrm{Sr} /{ }^{86} \mathrm{Sr}=0.7091\right)$. This $\mathrm{Sr}$ presumably is located in the smectites, which, as the main secondary minerals throughout the hole, replace olivine and matrix glass and locally fill vesicles (analyzed samples contained no veins).

The strontium-isotope data strongly suggest that the integrated flux of sea water through the upper part of the Hole 504B crust has been greater than through the lower part. This is also suggested by (1) the common occurrence of Feoxide-hydroxide minerals as alteration products above $\mathbf{2 7 0}$ meters, but their near absence below 320 meters, (2) the presence of vein calcite above 320 meters, but its near absence below this level, and (3) the occurrence of vein pyrite only below a depth of 270 meters. Sea-water circulation in the lower basalts may have been partly restricted by the greater number of relatively impermeable massive lava flows below 230 meters sub-basement. Although sufficient sea water was present within the lower part of the hole to produce smectitic alteration products, the overall water/rock ratio was low enough to prevent significant modification of strontium-isotope ratios.

Lead-isotope ratios of Hole 504B basalts form approximately linear arrays in plots of ${ }^{208} \mathrm{~Pb} /{ }^{204} \mathrm{~Pb}$ and ${ }^{207} \mathrm{~Pb} /{ }^{204} \mathrm{~Pb}$ versus ${ }^{206} \mathrm{~Pb} /{ }^{204} \mathrm{~Pb}$. The arrays are similar to those reported for basalts from other mid-ocean ridges. There is no trend in Hole 504B lead-isotope ratios with vertical position in the basement. The arrays indicate that the lead-isotope composition of the upper mantle from which the Hole 504B basaltic melts were derived was inhomogeneous.
\end{abstract}

\section{INTRODUCTION}

Strontium- and lead-isotope ratios of fresh oceanic basalts provide information on primary isotopic variations in the mantle source rocks from which the basalts were derived (Tatsumoto, 1966; Peterman and Hedge, 1971; O'Nions and Pankhurst, 1974; Church and Tatsumoto, 1975; Hart, 1976; Wood et al., 1979). Fresh mid-ocean-ridge (MOR) basalts display a relatively restricted range of strontium-isotope compositions, but a more extensive range of lead-isotope compositions. Basalts which have been affected by sea-water alteration have had their primary strontium-isotope composition modified toward the strontium-isotope composition of sea water (Dasch et al., 1973; Hart et al., 1974; Spooner et al., 1977; Satake and Matsuda, 1979). Altered basalts therefore display increased ${ }^{87} \mathrm{Sr} /{ }^{86} \mathrm{Sr}$ ratios relative to the primary ratios of the unaltered basalts; the increase depends on the extent to which sea-water strontium has been incorporated into the basalt during the formation of secondary minerals. Lead-isotope ratios, on the other

\footnotetext{
${ }^{1}$ Cann, J. R., Langseth, M. G., Honnorez, J., Von Herzen, R. P., White, S. M., et al., Init. Repts. DSDP, 69: Washington (U.S. Govt. Printing Office).

2 Present address: Dept. of Geology, University of Toronto, Toronto, Ontario MSS 1A1, Canada.
}

hand, are not thought to be affected by sea-water alteration and therefore reflect primary petrological processes.

Previous strontium- and/or lead-isotope studies of oceanic basalts generally have been carried out on dredged samples, and on the cored samples recovered by DSDP Legs 34, 37, 45, 51, 52, and 53. Hole 504B, Legs 69 and 70 , penetrated 562.5 meters into basalt basement, making it one of the deepest holes drilled to date, and the deepest hole in the eastern Pacific. It provides an excellent opportunity to examine vertical variations in the strontium- and lead-isotope composition of the upper oceanic crust. Of particular interest is the degree to which sea water has altered the strontium-isotope composition of the basalts, because the Hole 504B crust is quite young (5.9 m.y.).

\section{SAMPLES AND ANALYTICAL PROCEDURES}

Seventeen whole-rock samples, generally taken at 25- to 50-meter intervals, were analyzed for ${ }^{87} \mathrm{Sr} /{ }^{86} \mathrm{Sr}$ ratios, and rubidium and strontium concentrations. Ten of these samples also were analyzed for leadisotope compositions. All samples, with one exception, were taken from crystalline pillows or massive basalt. Local breccia zones were not sampled. Although Hole 504B basalts commonly contain veins of smectite, calcite, or zeolites, the samples selected for analysis contained no visible veins, because the object of the study was to determine the isotopic composition solely of the basaltic material. However, one sample of glass from a pillow margin, partly altered to smectite, also was included in the study. Obvious zones of alteration near veins and fractures, which were up to a few centimeters in thickness, also were 
not sampled. The samples taken were of uniform megascopic appearance in terms of color and texture.

Whole-rock samples weighing 60 to 70 grams were broken into centimeter-sized fragments, rinsed in de-ionized water, crushed in a stainless-steel mortar, and ground to a fine powder in an agate planetary ball mill. Lead was extracted from whole-rock powder splits by dissolution, followed by the electrodeposition technique of Arden and Gale (1973). Samples were mounted on a single Re filament, using a silica-gel-phosphoric-acid activator, and the analyses were made on the Oxford 12-inch solid-source mass spectrometer designed by Dr. N. H. Gale. Lead-isotope data have been corrected for mass fractionation by comparison with results on Standard NBS 981. Typical errors on lead-isotope ratios are 0.1 to $0.15 \%$. Strontium was extracted from powder splits by standard ion-exchange methods (O'Nions and Pankhurst, 1973), and analyzed on a V. G. MM-30 mass spectrometer. ${ }^{87} \mathrm{Sr} /{ }^{86} \mathrm{Sr}$ ratios have been normalized to a value of 0.70800 for the Eimer and Amend strontium standard. Typical errors on ${ }^{87} \mathrm{Sr} /{ }^{86} \mathrm{Sr}$ measurements are $0.01 \%$. Rubidium and strontium concentrations were determined by X-ray fluorescence. The errors in strontium concentration are not more than $\pm 5 \%$; the rubidium data, however, should be considered semi-quantitative, because of the low concentrations levels.

\section{STRONTIUM ISOTOPES}

Strontium-isotope data for the 17 samples are given in Table 1, together with strontium and rubidium concentrations, lithological descriptions, and type of sample alteration. Samples are listed in their order of occurrence from top (No. 1) to bottom (No. 17) of the hole. Strontium-isotope compositions are plotted as a function of sub-basement depth in Figure 1; rubidium and strontium concentrations and the $\mathrm{Rb} / \mathrm{Sr}$ ratio are plotted as a function of depth in Figure 2.

The eight samples from the upper 260 meters of the hole, down to and including Core 34 , have ${ }^{87} \mathrm{Sr} / 86 \mathrm{Sr}$ ratios of 0.70287 to 0.70377 (with an average of 0.70320 ), strontium contents of 64.6 to $78.5 \mathrm{ppm}$, and rubidium contents of 1.3 to $9.5 \mathrm{ppm}$. By contrast, ${ }^{87} \mathrm{Sr} /$ ${ }^{86} \mathrm{Sr}$ ratios for the five samples from the lower $230 \mathrm{me}-$ ters of the hole have a more restricted range, from 0.70255 to 0.70279 , with an average of 0.70266 . This mean value is nearly identical to the average value of 0.70265 given by Hart (1976) for fresh dredged MOR basalts (17 samples), and to the average value of 0.70267 for three fresh basalts from the Nazca Plate, DSDP Leg 34 (Hart, 1976). It also closely corresponds to the average of 0.70259 for nine MOR basalt glasses reported by Cohen et al. (1980) (their samples 2 and 3 are omitted from this average because they are from crust generated at non-typical segments of the Mid-Atlantic Ridge, the $46^{\circ} \mathrm{N}$ area and the Azores area, respectively [White and Schilling, 1978; O'Nions and Pankhurst, 1974]). Strontium contents of the lowest five samples range from 53.3 to $73.2 \mathrm{ppm}$, and rubidium contents from 0.1 to 0.5 ppm. Sample No. 15 has both the highest ${ }^{87} \mathrm{Sr} /{ }^{86} \mathrm{Sr}$ ratio and rubidium content in the lowest 200 meters, but is omitted from the average because it is an altered glass from a pillow margin. In a limited interval $(260-330 \mathrm{~m})$ in the middle part of the hole, ${ }^{87} \mathrm{Sr} /{ }^{86} \mathrm{Sr}$ values are approximately intermediate between those for the upper and lower parts of the hole.

The higher ${ }^{87} \mathrm{Sr} /{ }^{86} \mathrm{Sr}$ ratios of the basalts in the upper part of the hole can be interpreted in terms of isotopic alteration during basalt-sea-water interaction (cf. Dasch et al., 1973; Hart et al., 1974). Sea water presently has a
${ }^{87} \mathrm{Sr} /{ }^{86} \mathrm{Sr}$ ratio of $0.70910 \pm 6$ (Veizer and Compston, 1974). Assuming that the basalts in the upper part of the hole initially had an average ${ }^{87} \mathrm{Sr} / 86 \mathrm{Sr}$ ratio of 0.70265 , their present range of values implies a 3 to $17 \%$ contribution of sea-water strontium, with an average addition of about $9 \% \mathrm{Sr}$. The basalts in the lower part of the hole have incorporated essentially no sea-water strontium.

A greater degree of basalt-sea-water interaction in the upper part of Hole 504B is independently suggested by whole-rock $\mathrm{K}_{2} \mathrm{O}$ contents. Hubberten et al. (this volume) found that $\mathrm{K}_{2} \mathrm{O}$ contents decrease abruptly below a depth of about 280 meters sub-basement. $\mathrm{K}_{2} \mathrm{O}$ contents of basalts are known to be increased as a result of lowtemperature $\left(<150^{\circ} \mathrm{C}\right)$ sea-water alteration (Hart and Staudigel, 1969; Seyfried and Bischoff, 1979; Staudigel et al., 1979). During low-temperature sea-water alteration, rubidium also is added to basalt (Hart, 1969; Hart and Staudigel, 1980). The average rubidium content of fresh MOR basalts is about $1.0 \mathrm{ppm}$ (Hart, 1976). The rubidium data in Table 1, although semi-quantitative, are consistent with the addition of rubidium to upper basalts (1.3-9.5 ppm Rb), but not to lower basalts $(\leq 0.5 \mathrm{ppm})$.

The upper part of the hole is also clearly more oxidized than the lower part. Partial alteration of olivine phenocrysts and matrix glass to Fe-oxide-hydroxides is common from 0 to 270 meters, less common from 270 to 320 meters, and nearly absent below $\mathbf{3 2 0}$ meters. Calcite is present in veins and locally as a replacement mineral above 320 meters, but is rare below. Pyrite is absent from 0 to 270 meters sub-basement, but present in veins below this level Honnorez et al. (this volume). These observations are consistent with a greater total flux of oxidizing sea water through the upper 270 meters of the crust than through the 320 - to 560-meter interval; within the latter interval, ambient waters apparently were relatively reduced (as inferred from the presence of pyrite) and relatively acidic (as inferred from the absence of calcite). These observations suggest that pore waters were relatively stagnant, and are consistent with chemical changes in sea water experimentally reacted with basalts at low water/rock ratios (Mottl and Holland, 1978).

The main alteration product in the analyzed basalts is greenish smectite, which has a general modal abundance of 5 to $10 \%$. Throughout the hole, this smectite pseudomorphs olivine phenocrysts, replaces interstitial glass matrix, and locally is present within vesicles. Hence, this mineral is the likely sink for any sea-water strontium which is added to the basalts during alteration. It is of interest that although ${ }^{87} \mathrm{Sr} /{ }^{86} \mathrm{Sr}$ ratios are higher in the upper part of the hole than in the lower part, the relative proportions of (non-vein) secondary smectites, as ascertained by petrographic examination, are roughly the same. Thus, sufficient sea water was present throughout the crust to produce smectitic alteration from the top to the bottom of the hole; however, only in the upper half of the hole was the total flux of sea water high enough to produce modified strontium-isotope compositions.

Hole 504B basalts are low in strontium (53-79 ppm) relative to the average MOR basalt value of $124 \mathrm{ppm}$ given by Hart (1976), and the average values of about 
Table $1 .{ }^{87} \mathrm{Sr} /{ }^{86} \mathrm{Sr}$ ratios, $\mathrm{Rb}$ and $\mathrm{Sr}$ concentrations, and sample descriptions.

\begin{tabular}{|c|c|c|c|c|c|c|}
\hline Sample & $\begin{array}{c}\text { DSDP } \\
\text { Sample No. }\end{array}$ & Lithology & Alteration ${ }^{\mathrm{a}}$ & $\underset{\text { (ppm) }}{\mathrm{Rb}}$ & $\begin{array}{c}\mathrm{Sr} \\
(\mathrm{ppm})\end{array}$ & ${ }^{87} \mathrm{Sr} /{ }^{86} \mathrm{Sr}_{\mathrm{r}}^{\mathrm{b}}$ \\
\hline 1 & $\begin{array}{l}\text { 504B-3-1 } \\
\quad \text { (Piece 253, } \\
\text { 102-105 cm) }\end{array}$ & $\begin{array}{l}\text { Fine-grained aphyric basalt; } \\
\text { pillow or thin flow ( } 80 \mathrm{~cm} \\
\text { thick); sample from middle }\end{array}$ & G,R & 3.6 & 68.8 & $0.70377 \pm 6$ \\
\hline 2 & $\begin{array}{l}\text { 504B-8-3 } \\
\quad \text { Piece } 540 \\
75-80 \mathrm{~cm})\end{array}$ & $\begin{array}{l}\text { Medium-grained, sub-aphyric } \\
\text { basalt; massive flow (at } \\
\text { least } 1.5 \mathrm{~m} \text { thick); sample } \\
\text { from middle }\end{array}$ & G & 2.5 & 69.4 & $0.70316 \pm 6$ \\
\hline 3 & $\begin{array}{l}\text { 504B-13-2 } \\
\text { (Piece 779, } \\
86-89 \mathrm{~cm} \text { ) }\end{array}$ & $\begin{array}{l}\text { Fine-grained aphyric basalt; } \\
\text { pillow or thin flow; } \\
\text { sample from middle }\end{array}$ & $G, R$ & 9.5 & 74.0 & $0.70337 \pm 5$ \\
\hline 4 & $\begin{array}{l}\text { 504B-19-2 } \\
\text { (Piece 1145, } \\
82-85 \mathrm{~cm})\end{array}$ & $\begin{array}{l}\text { Fine-grained moderately } \\
\text { Pl-Ol-Cpx-phyric basalt; } \\
\text { pillow; sample from middle }\end{array}$ & G & 2.0 & 64.6 & $0.70318 \pm 4$ \\
\hline 5 & $\begin{array}{l}\text { 504B-25-2 } \\
\text { (Piece 1434, } \\
\text { 97-101 cm) }\end{array}$ & $\begin{array}{l}\text { Fine-grained aphyric basalt; } \\
\text { pillow or thin flow ( } 55 \\
\mathrm{~cm} \text { thick); sample from middle }\end{array}$ & G & 6.2 & 74.1 & $0.70287 \pm 5$ \\
\hline 6 & $\begin{array}{l}\text { 504B-29-1 } \\
\text { (Piece 1569, } \\
\text { 50-52 cm) }\end{array}$ & $\begin{array}{l}\text { Fine-grained aphyric basalt, } \\
\text { probably pillow material }\end{array}$ & G & - & - & $0.70291 \pm 5$ \\
\hline 7 & $\begin{array}{l}\text { 504B-33-1 } \\
\quad \text { (Piece 184, } \\
\text { 28-30 cm) }\end{array}$ & $\begin{array}{l}\text { Medium-grained highly Ol-Pl- } \\
\text { phyric basalt; massive unit } \\
(\sim 3 \mathrm{~m} \text { thick); sample from } \\
\sim 70 \mathrm{~cm} \text { below top }\end{array}$ & $G, R$ & 1.3 & 78.5 & $0.70291 \pm 4$ \\
\hline 8 & $\begin{array}{l}\text { 504B-34-2 } \\
\text { (Piece 242, } \\
\text { 32-37 cm) }\end{array}$ & $\begin{array}{l}\text { Fine-grained moderately } \\
\text { Pl-Ol-phyric basalt; pillow; } \\
\text { sample from margin }\end{array}$ & $G, R$ & 1.4 & 67.4 & $0.70340 \pm 6$ \\
\hline 9 & $\begin{array}{l}\text { 504B-36-2 } \\
\text { (Piece 307, } \\
\text { 44-46 cm) }\end{array}$ & $\begin{array}{l}\text { Medium-grained moderately Pl- } \\
\text { phyric basalt; massive unit } \\
\sim 6 \mathrm{~m} \text { thick); sample from } \\
\sim 2 \mathrm{~m} \text { below top }\end{array}$ & G,P & 0.0 & 58.2 & $0.70262 \pm 7$ \\
\hline 10 & $\begin{array}{l}\text { 504B-38-1 } \\
\text { (Piece 420, } \\
\text { 90-92 cm) }\end{array}$ & $\begin{array}{l}\text { Medium-grained moderately } \\
\text { Ol-Pl-Cpx-phyric basalt; } \\
\text { Pillow interior }\end{array}$ & G,R,P & - & - & $0.70306 \pm 5$ \\
\hline 11 & $\begin{array}{l}\text { 504B-41-2 } \\
\text { (Piece 599, } \\
17-19 \mathrm{~cm})\end{array}$ & $\begin{array}{l}\text { Medium-grained moderately } \\
\text { Pl-Ol-phyric basalt; mas- } \\
\text { sive flow }(\sim 14 \mathrm{~m} \text { thick }) \text {; sam- } \\
\text { ple from } \sim 3 \mathrm{~m} \text { above base }\end{array}$ & G & - & - & $0.70296 \pm 5$ \\
\hline 12 & $\begin{array}{l}\text { 504B-46-1 } \\
\text { (Piece 778, } \\
\text { 112-116 cm) }\end{array}$ & $\begin{array}{l}\text { Fine-grained sparsely Pl- } \\
\text { phyric basalt; pillow; sam- } \\
\text { ple from margin }\end{array}$ & G & 0.1 & 60.8 & $0.70259 \pm 7$ \\
\hline 13 & $\begin{array}{l}\text { 504B-52-3 } \\
\text { (Piece 1030, } \\
\text { 62-65 cm) }\end{array}$ & $\begin{array}{l}\text { Medium-grained sparsely Ol- } \\
\text { Pl-phyric basalt; massive } \\
\text { unit (at least } 4 \mathrm{~m} \text { thick); } \\
\text { sample from middle }\end{array}$ & G,P & 0.5 & 60.2 & $0.70269 \pm 5$ \\
\hline 14 & $\begin{array}{l}\text { 504B-57-1 } \\
\text { (Piece 1139, } \\
83-88 \mathrm{~cm})\end{array}$ & $\begin{array}{l}\text { Fine-grained moderately Pl- } \\
\text { Ol-phyric basalt; pillow; } \\
\text { sample from margin }\end{array}$ & G & 0.2 & 73.2 & $0.70279 \pm 4$ \\
\hline 15 & $\begin{array}{l}\text { 504B-63-4 } \\
\text { (Piece 1393, } \\
5-8 \mathrm{~cm})\end{array}$ & $\begin{array}{l}\text { Glassy pillow rim; glass } \\
\text { partly altered to green } \\
\text { smectite }\end{array}$ & G & 2.8 & 62.5 & $0.70465 \pm 7$ \\
\hline 16 & $\begin{array}{l}\text { 504B-64-2 } \\
\quad \text { Piece 1436, } \\
125-130 \mathrm{~cm} \text { ) }\end{array}$ & $\begin{array}{l}\text { Medium-grained aphyric basalt; } \\
\text { massive flow }(\sim 1.5 \mathrm{~m} \\
\text { thick); sample from lower } \\
\text { portion }\end{array}$ & G,P & 0.3 & 53.3 & $0.70268 \pm 7$ \\
\hline 17 & $\begin{array}{l}\text { 504B-70-2 } \\
\text { (Piece 1563, } \\
\text { 3-7 cm) }\end{array}$ & $\begin{array}{l}\text { Coarse-grained ophitic basalt; } \\
\text { massive flow (or sill) } \\
\text { of unknown thickness; sample } \\
\text { from } \sim 25 \mathrm{~cm} \text { below top }\end{array}$ & G & 0.1 & 59.8 & $0.70255 \pm 6$ \\
\hline \multirow{3}{*}{\multicolumn{4}{|c|}{$\begin{array}{l}\text { Average of samples } 1 \text { to } 8 \text { inclusive } \\
\text { Average of samples } 9 \text { to } 11 \text { inclusive } \\
\text { Average of samples } 12 \text { to } 17 \text { inclusive (except 15) }\end{array}$}} & 3.8 & 69.5 & 0.70320 \\
\hline & & & & $\overline{03}$ & $-\overline{-}$ & 0.70286 \\
\hline & & & & 0.3 & 61.4 & 0.70266 \\
\hline
\end{tabular}

Note: $\mathrm{H}_{2} \mathrm{O}^{+}$determined for several samples as follows (in \%): $1: 0.90,0.97 ; 2: 0.72 ; 7: 1.56,1.63 ; 8: 0.79 ; 10$ : $0.67 ; 12: 5.84 ; 13: 0.78$; samples analyzed by Penfield tube method.

a $\mathrm{G}=$ colorless to green smectites occurring as alteration products of olivine and glass, and as vesicle fillings.

$\mathrm{R}=$ reddish-brown alteration minerals indicative of relatively oxidizing conditions (hematite, Fe-hydroxide, iddingsite), occurring as alteration products of olivine and glass, and as vesicle fillings.

$\mathbf{P}=$ pyrite, indicative of relatively reducing conditions; where pyrite is indicated, it is not present in the sample, but in veins within $30 \mathrm{~cm}$ above or below it.

brrors on the ${ }^{87} \mathrm{Sr} / 86 \mathrm{Sr}$ ratios are 2 standard errors of the mean.

$110 \mathrm{ppm}$ for Site 332 (Yamaguchi et al., 1976; Gray et al., 1976), and $115 \mathrm{ppm}$ for Sites 417 and 418 (Staudigel et al., 1980). This is not an analytical effect, as analyses performed elsewhere yielded similarly low values (Etoubleau et al., this volume). The higher strontium contents of the upper basalts relative to the lower basalts may in- dicate that simple addition of sea-water strontium has been more important than isotopic exchange between sea water and basaltic sea-water strontium during alteration. Calculations show that the average 8-ppm increase in strontium in the upper basalts, if the result of simple addition from sea water, more than accounts for 


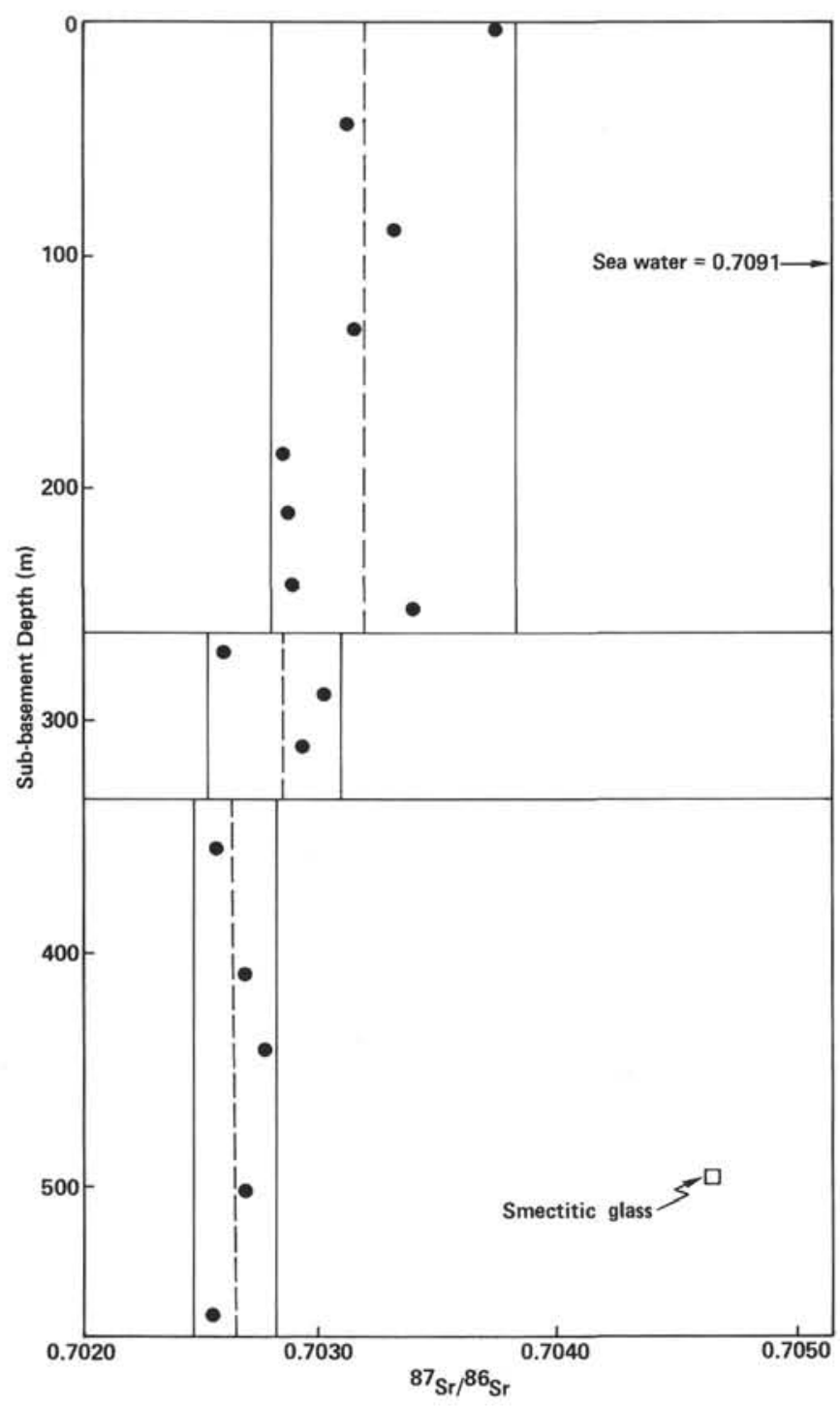

Figure $1 .{ }^{87} \mathrm{Sr} /{ }^{86} \mathrm{Sr}$ ratios versus sub-basement depth for basalts from Hole 504B, Costa Rica Rift. The solid vertical lines give the range in ${ }^{87} \mathrm{Sr} /{ }^{86} \mathrm{Sr}$ ratios for a given section of the hole; the dashed lines represent the mean. The horizontal divisions between sections are arbitrarily drawn halfway between flanking data points. An altered-glass sample (open square) is not included in the lower-hole average.

their higher average ${ }^{87} \mathrm{Sr} /{ }^{86} \mathrm{Sr}$ ratio (except for sample 1 , where some strontium-isotope exchange also would be required).

The glass sample with smectite alteration (No. 15, Table 1) has a high ${ }^{87} \mathrm{Sr} /{ }^{86} \mathrm{Sr}$ ratio of 0.70465 , which suggests a $30 \%$ sea-water-strontium component; however, by contrast with upper-hole samples, it appears to have essentially no strontium enrichment (Fig. 2), suggesting that for this sample strontium-isotope exchange has been the dominant process during alteration. The high ${ }^{87} \mathrm{Sr} /$ ${ }^{86} \mathrm{Sr}$ ratio of this sample, which is from a sub-basement depth of 490 meters, indicates that sea-water-derived strontium was incorporated at least locally into the lower basalts. However, since the analyzed crystalline mas-
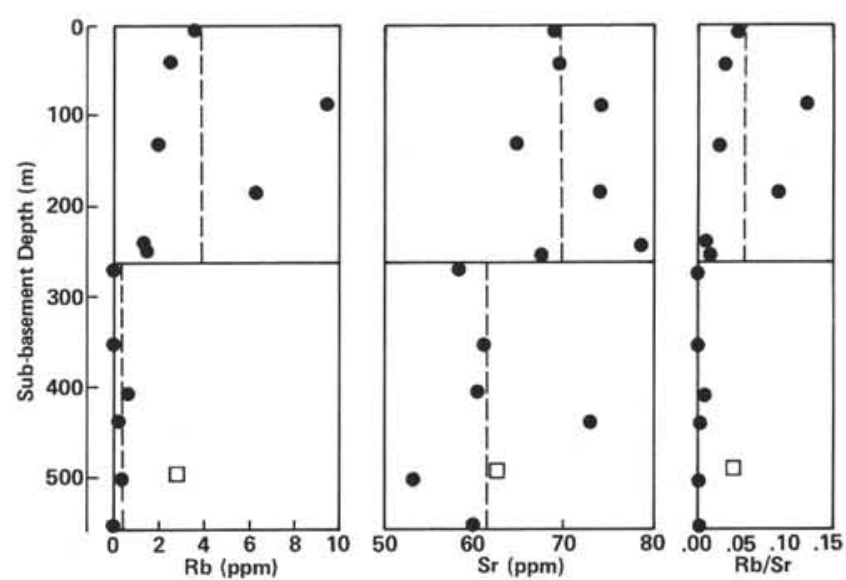

Figure 2. Rubidium and strontium contents and $\mathrm{Rb} / \mathrm{Sr}$ ratio versus sub-basement depth for basalts from Hole 504B, Costa Rica Rift. The dashed lines represent mean values for the upper and lower parts of the hole. An intermediate section of the hole has not been distinguished (as in Fig. 1), because of fewer data in this interval. An altered-glass sample (open square) is not included in the lowerhole average.

sive flows and pillow margins from this part of the hole show very low ${ }^{87} \mathrm{Sr} /{ }^{86} \mathrm{Sr}$ ratios, strontium-isotope alteration probably has affected only their volumetrically insignificant glassy rims (and possibly also alteration halos close to veins and fractures, which were not sampled).

Leg 37 (Holes 332-335), on the Mid-Atlantic Ridge, drilled 583 meters into 3.5-m.y.-old basement at Site 332 (Aumento, Melson, et al., 1977). ${ }^{87} \mathrm{Sr} /{ }^{86} \mathrm{Sr}$ ratios throughout these holes have a range from 0.70293 to 0.70339 , and an average of 0.70312 , both of which are very similar to those of the upper 260 meters of Hole 504B. Rubidium contents also have a comparable range of 1 to $7 \mathrm{ppm}$ (O'Nions and Pankhurst, 1977; Yamaguchi et al., 1977). Similar data for Site 332, with a mean of 0.70331 (calcite-free samples), were reported by Gray et al. (1977). These data suggest that strontium-isotope alteration by sea water has occurred to a depth of at least 580 meters at Site 332.

In the western Atlantic, Hole 418A (Legs 51-53) penetrated 544 meters into 110 -m.y.-old crust generated at the Mid-Atlantic Ridge (Donnelly et al., 1980). ${ }^{87} \mathrm{Sr} /{ }^{86} \mathrm{Sr}$ ratios of the basalts were similar to and higher than those of the Site 335 basalts, with a range of 0.70313 to 0.70761 , and a mean of 0.70421 ; these ratios indicate strontium-isotope alteration to at least 500 meters subbasement (Staudigel et al., 1980). These higher ratios are consistent with an even longer period of exposure to circulating sea water than in the case of the Hole 335 basalts. Although Hart and Staudigel (1979) and Richardson et al. (1980) provide evidence that circulation of sea water through Hole 418A basalts was not important more than 10 m.y. after the basalts were formed, the decrease in both convective heat transfer and the thickness of Layer $2 \mathrm{~A}$ to zero in approximately $60-\mathrm{m}$.y.-old Atlantic crust argue that some convection can occur in non-sealed basement as much as $60 \mathrm{~m}$.y. after its formation (Anderson et al., 1977; Salisbury et al., 1980). 


\section{GENERAL DISCUSSION}

The trend in ${ }^{87} \mathrm{Sr} /{ }^{86} \mathrm{Sr}$ ratios with depth in Hole 504B has been ascribed above to a greater total flux of sea water through the upper part of the hole than in the lower part during the 5.9 m.y. since the crust was formed. Although some primary magmatic variation in strontium-isotope composition initially may have existed throughout the hole, it probably was limited in degree if the basalts were typical MOR basalts. Fresh MOR basalts normally have values between 0.7023 and 0.7029 , with a clustering of values about $0.70265 \pm 0.0002$ (Hofmann and Hart, 1978; Cohen et al., 1980). The limited range in strontium-isotope composition observed in the lower part of Hole 504B (0.70255-0.70279) could therefore reflect primary magmatic variation. However, a small component of sea-water-derived strontium cannot be ruled out in the case of the highest value within this range (sample 14).

The extent to which primary strontium-isotope ratios (and other geochemical characteristics) are affected by sea-water alteration is influenced by the overall flux of sea water through the crust, and the temperature of sea-water-basalt interaction (which influences reaction rates). The overall flux is determined by the intensity and depth of penetration of faults and fractures within the crust, the proportions of relatively permeable and impermeable materials in the crust (i.e., pillow lavas and flow breccias versus massive lavas), and the effectiveness of overlying sediments in sealing off the crust from convective circulation.

At fast-spreading ridges, such as the East Pacific Rise, vigorous circulation of sea water through the crust occurs, and high sea-water temperatures are achieved (Edmond et al., 1979; Corliss et al., 1979). These conditions should favor more-intense and pervasive isotopic alteration. Both the Troodos and Oman ophiolite complexes display isotopic evidence of extensive and deep penetration of sea-water alteration (Spooner et al., 1977; Heaton and Sheppard, 1977; McCulloch et al., 1980). The metalliferous sediments and sulfide deposits overlying the ophiolitic basalts (Constantinou and Govett, 1972; Robertson and Hudson, 1973; Spooner and Bray 1977; Fleet and Robertson, 1980) suggest that these ophiolites were formed at ridges analogous to the East Pacific Rise, where similar modern deposits have been found (Boström, 1973; Francheteau et al., 1979; Corliss et al., 1979).

The basalts of Hole 504B were generated 5.9 m.y. ago at the Costa Rica Rift. The half spreading rate over the last $8 \mathrm{~m} . y$. for the southern flank of the Rift has been $3.3 \mathrm{~cm} / \mathrm{yr}$ (Hey, 1975). This is intermediate between the half spreading rates of ridges such as the MidAtlantic Ridge and Gorda Ridge $(0.7-1.5 \mathrm{~cm} / \mathrm{yr}$; Needham and Francheteau, 1974) and the East Pacific Rise $\left(\sim 8 \mathrm{~cm} / \mathrm{yr}\right.$ at $31^{\circ} \mathrm{S}$; Rea, 1977). However, it is very close to the value for the Galapagos spreading axis, which locally is characterized by intensive high-temperature hydrothermal circulation (Edmond et al., 1979). The overall rather limited degree of strontium-isotope alteration recorded for Hole 504B is therefore somewhat surprising. It appears that the point of formation of Hole 504B crust and the line along which the crust moved away from the Costa Rica Rift axis were not sites of sustained intensive hydrothermal circulation.

The lower degree of strontium-isotope alteration in the lower part of Hole 504B, relative to the upper part, may be related to the greater proportion of massive lava flows below about 230 meters sub-basement. These massive flows, up to 15 meters thick, should serve to decrease the average permeability of the crust, because massive flows are internally much less fractured than pillows, and may act as seals to reduce the flux of sea water through underlying basalts. Evidence from packer and heat-flow experiments in Hole 504B indicate that the lower part of the hole is presently much less permeable than the upper part (Becker et al., this volume; Langseth et al., this volume; Zoback and Anderson, this volume). Permeability also may have been decreased in the lower part of the hole as a result of filling of voids by secondary minerals, or by reduction in void space by overburden pressure.

As mentioned in the previous section, strontium-isotope alteration is more pronounced and extends to greater depth in young (3.5-m.y.-old) Mid-Atlantic Ridge crust than in Hole 504B crust. This may be related to the fact that slow-spreading ridges are more strongly dissected by numerous deep faults than fast-spreading ridges. Such fault systems could allow more extensive penetration of sea water through the crust. The even more extensive strontium-isotope alteration of 110-m.y.old crust in the western Atlantic may result from an additional factor, that is, a significantly longer period of exposure to circulating sea water. Convection of sea water through basement continues longer in slow-spreading crust than in fast-spreading crust, because of incomplete burial of basement relief by the sediment cover (Anderson et al., 1977).

Wolery and Sleep (1976) have calculated that hydrothermal circulation theoretically should cease at fastspreading ridges and slow-spreading ridges after 6 to 14 m.y. and 11 to 19 m.y., respectively. Circulation at the Costa Rica Rift therefore might be expected to operate within the crust for an intermediate time, on the order of $10 \mathrm{~m} . \mathrm{y}$. However, heat-flow data indicate that convective circulation lasts only about $5 \mathrm{~m} . \mathrm{y}$. (Anderson and Hobart, 1976). The early cessation of circulation at the Costa Rica Rift apparently is related to the 275-meter-thick sediment section overlying the basement. This unusually thick sequence, the result of sedimentation within the equatorial high-productivity belt, has resulted in early sealing of convective circulation (Anderson and Hobart, 1976).

If the pore waters within the Hole 504B basalts are not being replaced by new sea water through convective circulation, then almost no further detectable strontium-isotope alteration should occur in the future. Suppose that the average porosity for the lower part of the hole is $10 \%$ (a probable maximum value), and that the sea water occupying the spaces is not being replenished. The average strontium content of the basalts is about 60 $\mathrm{ppm}$, and of seawater $8 \mathrm{ppm}$. If all of the sea-water strontium is incorporated into the basalts, an original ${ }^{87} \mathrm{Sr} /{ }^{86} \mathrm{Sr}$ ratio of 0.7027 would be increased to only 
0.7028 . In order to obtain the average ${ }^{87} \mathrm{Sr} /{ }^{86} \mathrm{Sr}$ ratio of 0.7032 for the upper 260 meters of Hole 504B basalts, replacement of pore waters (for $10 \%$ porosity) must have occurred ten times, giving an integrated water/ rock ratio of 1.0. This figure is minimal, because strontium extraction from sea water would not have been $100 \%$ efficient.

\section{LEAD ISOTOPES}

Lead-isotope compositions are listed in Table 2. The lead-isotope compositions are plotted in Figure 3 together with data from other MOR basalts for comparison. The data form approximately linear arrays similar to those previously reported for basalts from mid-ocean ridges such as the Mid-Atlantic Ridge (M.A.R.), Reykjanes Ridge (R.R.) and East Pacific ridges (E.P.r., including Gorda Ridge, Juan de Fuca Ridge, and East Pacific Rise). In detail, the Hole 504B arrays plot in a position between M.A.R. basalts (Leg 37) and basalts from the East Pacific ridges. The lead-isotope ratios within Hole 504B basalts display no vertical trends; the distribution of values with depth appears to be random.

Lateral inhomogeneity in the lead isotope composition of the mantle underlying oceanic ridges has been clearly demonstrated by previous studies of dredged basalts. Tatsumoto $(1966,1978)$ reported considerable leadisotope variations among three samples from the MidAtlantic Ridge (three samples from the East Pacific Rise showed somewhat less variation). Church and Tatsumoto (1975) found significant variations among 17 samples from the Gorda Ridge and Juan de Fuca Ridge in the east Pacific.

Table 2. Lead-isotope data for basalts from Hole 504B, Costa Rica Rift.

\begin{tabular}{|c|c|c|c|c|}
\hline Sample & $\begin{array}{c}\text { DSDP } \\
\text { Sample No. }\end{array}$ & ${ }^{206} \mathrm{~Pb} /{ }^{204} \mathrm{~Pb}$ & ${ }^{207} \mathrm{~Pb} /{ }^{204} \mathrm{~Pb}$ & ${ }^{208} \mathrm{~Pb} /{ }^{204} \mathrm{~Pb}$ \\
\hline 1 & $\begin{array}{l}\text { 504B-3-1 } \\
\text { (Piece 253, } \\
102-105 \mathrm{~cm} \text { ) }\end{array}$ & 18.245 & 15.544 & 37.912 \\
\hline 4 & $\begin{array}{l}\text { 504B-19-2 } \\
\text { (Piece 1145, } \\
82-85 \mathrm{~cm} \text { ) }\end{array}$ & 18.324 & 15.547 & 37.982 \\
\hline 6 & $\begin{array}{l}\text { 504B-29-1 } \\
\text { (Piece 1569, } \\
\text { 50-52 cm) }\end{array}$ & 18.539 & 15.588 & 38.244 \\
\hline 8 & $\begin{array}{l}\text { 504B-34-2 } \\
\text { (Piece 242, } \\
\text { 50-52 cm) }\end{array}$ & 17.881 & 15.508 & 37.478 \\
\hline 9 & $\begin{array}{l}\text { 504B-36-2 } \\
\text { (Piece 307, } \\
44-46 \mathrm{~cm} \text { ) }\end{array}$ & 17.868 & 15.521 & 37.478 \\
\hline 10 & $\begin{array}{l}\text { 504B-38-1 } \\
\text { (Piece 420, } \\
90-92 \mathrm{~cm} \text { ) }\end{array}$ & 18.352 & 15.518 & 37.950 \\
\hline 12 & $\begin{array}{l}504 \mathrm{~B}-46-1 \\
\text { (Piece 778, } \\
112-116 \mathrm{~cm} \text { ) }\end{array}$ & 18.180 & 15.510 & 37.733 \\
\hline 14 & $\begin{array}{l}\text { 504B-57-1 } \\
\text { (Piece 1139, } \\
83-88 \mathrm{~cm} \text { ) }\end{array}$ & 18.056 & 15.521 & 37.664 \\
\hline 16 & $\begin{array}{l}\text { 504B-64-2 } \\
\text { (Piece 1436, } \\
125-130 \mathrm{~cm} \text { ) }\end{array}$ & 18.146 & 15.497 & 37.728 \\
\hline 17 & $\begin{array}{l}\text { 504B-70-2 } \\
\text { (Piece 1563, } \\
3-7 \mathrm{~cm} \text { ) }\end{array}$ & 18.042 & 15.538 & 37.574 \\
\hline \multicolumn{2}{|c|}{ Standard NBS 981} & 16.904 & 15.449 & 36.564 \\
\hline
\end{tabular}

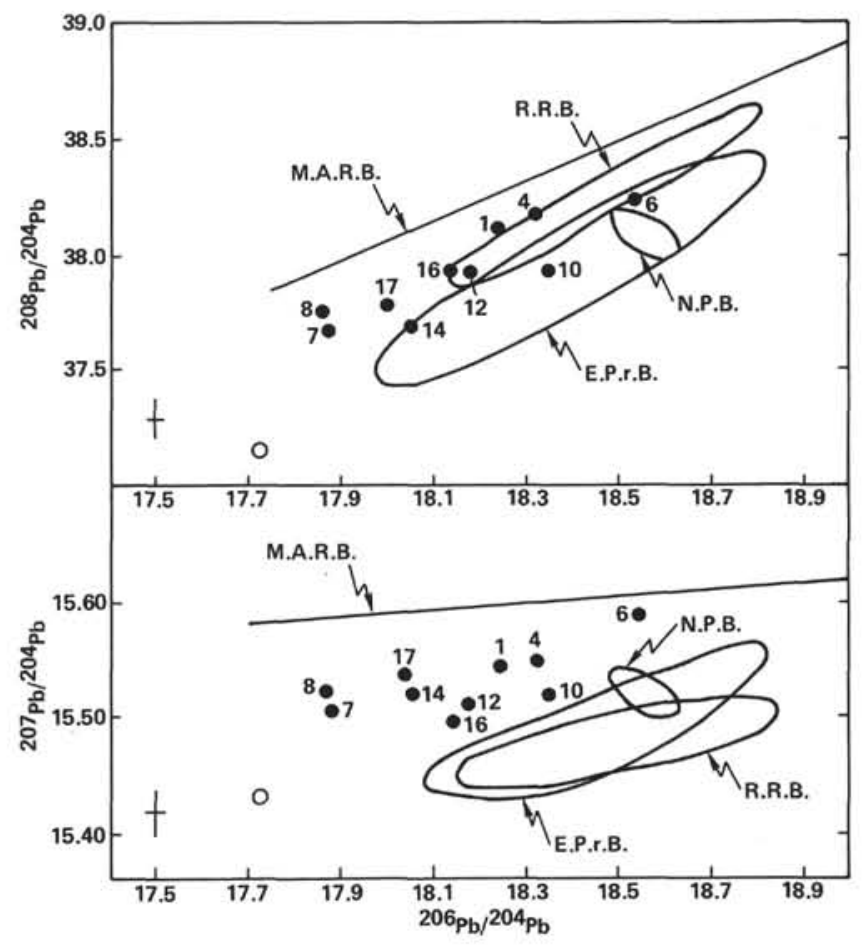

Figure 3. ${ }^{208} \mathrm{~Pb} /{ }^{204} \mathrm{~Pb}$ versus ${ }^{206} \mathrm{~Pb} /{ }^{204} \mathrm{~Pb}$ and ${ }^{207} \mathrm{~Pb} /{ }^{204} \mathrm{~Pb}$ versus ${ }^{206} \mathrm{~Pb}$ / ${ }^{204} \mathrm{~Pb}$ for basalts from Hole 504B, Costa Rica Rift. Also shown are the data fields for East Pacific ridge basalts (E.P.r.B.: Juan de Fuca and Gorda Ridges, Church and Tatsumoto, 1975; East Pacific Rise, Tatsumoto, 1978); Reykjanes Ridge basalts (R.R.B.: Sun et al., 1975), and Nazca Plate basalts (N.P.B.: only Site 319 basalts, Leg 34, Unruh and Tatsumoto, 1976), together with the bestfit lines of the data arrays of Mid-Atlantic Ridge basalts from Leg 37 (Cumming, 1976). Sample numbers correspond to those in Table 1 . The open circle represents a dredge sample from the Mid-Atlantic Ridge; two other dredge samples from this Ridge plot within the E.P.r.B. field (Tatsumoto, 1978; re-analysis of samples reported in Tatsumoto, 1966). Error bars are $2 \sigma$ errors.

Basalts recovered from a single drill hole provide data on the degree of lead-isotope homogeneity of the mantle underlying a particular site. Unruh and Tatsumoto (1976) reported a very restricted range of lead-isotope ratios over intervals of $\mathbf{4 2}$ meters (five samples) and 5 meters (three samples) in Holes 319A and 321, respectively, on the Nazca Plate. They concluded that the basalts (which were generated at the Galapagos rise 15 to 40 m.y. ago) were "extracted from a portion of the mantle in which the $\mathrm{Pb}$ isotopic composition is homogeneous, or that mantle convection and/or mixing proportions of partial melts between the mantle plume and the low velocity zone were constant from about 15 to 40 m.y. ago."

Cumming (1976), on the other hand, recorded considerable variation in lead-isotope ratios over an interval of about 315 meters at Site 332 (Leg 37) on the Mid-Atlantic Ridge. The present study found a similar degree of variation over an interval of 560 meters in Hole 504B. These data indicate that the magmas extruded during the building up of crust at a particular location on a spreading axis can be of variable lead-isotope composition. If the magma chamber from which the extruded melts are derived is large and well mixed, significant 
lead-isotope variations would not be expected (Tatsumoto, 1978). To produce variations with time in a wellmixed magma chamber, large pulses of magma with isotopically different lead would have to be regularly injected. Variations might more readily result in a poorly mixed magma chamber. In any case, the magma chamber which fed the Hole 504B basalts must have received magma derived from underlying upper mantle which was inhomogeneous in terms of $\mathrm{Pb}$-isotope composition.

\section{ACKNOWLEDGMENTS}

I am indebted to Dr. S. Moorbath for permission to use the isotope laboratory at Oxford, to Mr. Roy Goodwin for determination of three ${ }^{87} \mathrm{Sr} /{ }^{86} \mathrm{Sr}$ ratios and for preparation of three lead samples, and to $\mathrm{Mr}$. Clive Johnson for preparation of the strontium samples. I would like to thank Drs. P. Taylor, S. R. Hart, R. S. Cohen, S. M. F. Sheppard, and $\mathrm{S}$. Hoernes for reviewing an earlier version of this chapter and making numerous helpful suggestions. Dr. P. Taylor provided useful advice on mass spectrometer operation, and C. J. Bray assisted in sample preparation. This research was supported by a N.A.T.O. postdoctorate fellowship from the Natural Sciences and Research Council of Canada.

\section{REFERENCES}

Anderson, R. N., and Hobart, M. A., 1976. The relation between heat flow, sediment thickness, and age in the eastern Pacific $J$. Geophys. Res., 81:2968-2989.

Anderson, R. N., Langseth, M. G., and Sclater, J. G., 1977. The mechanisms of heat transfer through the floor of the Indian Ocean. J. Geophys. Res., 82:3391-3409.

Arden, J. W., and Gale, N. H., 1973. New electrochemical technique for the separation of lead at trace levels from natural silicates. Anal. Chem., 46:2-6.

Aumento, F., Melson, W. G., et al., 1977. Init. Repts. DSDP, 37: Washington (U.S. Govt. Printing Office).

Bostrom, K., 1973. The origin and fate of ferromanganoan active ridge sediments. Stockholm Contr. Geol., 27:147-243.

Church, S. E., and Tatsumoto, M., 1975. Lead isotope relations in oceanic ridge basalts from the Juan de Fuca-Gorda Ridge area, N.E. Pacific Ocean. Contr. Mineral. Petrol. 53:253-279.

Cohen, R. S., Evensen, N. M., Hamilton, P. J., and O'Nions, R. K., 1980. U-Pb, Sm-Nd and $\mathrm{Rb}-\mathrm{Sr}$ systematics of mid-ocean ridge basalt glasses. Nature, 283:149-153.

Constantinou, G., and Govett, G. J. S., 1972. Genesis of sulphide ore deposits, ochre and umber of Cyprus. Inst. Min. Metall. Trans., 81:B34-B46.

Corliss, J. B., Dymond, J., Gordon, L. I., Edmond, J. M., Von Herzen, R. P., Ballard, R. D., Green, K., Williams, D., Bainbridge, A. E., Crane, K., and van Andel, Tj. H., 1979. Submarine thermal springs on the Galapagos Rift. Science, 203:1073-1083.

Cumming, G. L., 1976. Lead isotope ratios in DSDP Leg 37 basalts. Can. J. Earth Sci., 31:179-183.

Dasch, E. J., Hedge, C. E., and Dymond, J. 1973. Effect of sea water interaction on strontium isotope composition of deep sea basalt. Earth Planet. Sci. Lett., 19:177-183.

Donnelly, T., Francheteau, J., Bryan, W., Robinson, P., Flower, M., Salisbury, M., et al., 1980. Init. Repts. DSDP, 51, 52, 53: Washington (U.S. Govt. Printing Office).

Edmond, J. M., Measures, C., Mangum, B., Grant, B., Sclater, F. R., Collier, R., and Hudson, A., 1979. On the formation of metalrich deposits at ridge crests. Earth Planet. Sci. Lett., 46:19-30.

Fleet, A. J., and Robertson, A. H. F., 1980. Ocean-ridge metalliferous and pelagic sediments of the Semail Nappe, Oman. J. Geol. Soc., 137:403-422.

Francheteau, J., Needham, H. D., Choukroune, P., Juteau, T., Seguret, M., Ballard, R. D., Fox, P. J., Normark, W., Carranza, A., Cordoba, D., Guerrero, J., Rangin, C., Bougault, H., Cambon, P., and Hekinian, R., 1979. Massive deep sea sulphide ore deposits discovered on the East Pacific Rise. Nature, 277:523-528.

Gray, J., Cumming, G. L., and Lambert, R. StJ., 1977. Oxygen and strontium isotopic compositions and thorium and uranium contents of basalts from DSDP 37 cores. In Aumento, F., Melson, W.
G., et al., Init. Repts. DSDP, 37: Washington (U.S. Govt. Printing Office), 607-609.

Hart, S. R., 1969. K, Rb, Cs contents and $\mathrm{K} / \mathrm{Rb}, \mathrm{K} / \mathrm{Cs}$ ratios of fresh and altered submarine basalts. Earth Planet. Sci. Lett., 6:295-303. 1976. LIL-element geochemistry, Leg 34 basalts. In Yeats, R. S., Hart, S. R., et al., Init. Repts. DSDP, 34: Washington (U.S. Govt. Printing Office), 283-288.

Hart, S. R., Erlank, A. J., and Kable, E. J. D., 1974. Sea floor basalt alteration: some chemical and isotopic effects. Contr. Mineral. Petrol., 44:219-230.

Hart, S. R., and Staudigel, H., 1980. Ocean crust-sea water interaction: Sites 417 and 418. In Donnelly, T., Francheteau, J., Bryan, W., Robinson, P., Flower, M., Salisbury, M., et al., Init. Repts. $D S D P, 51,52,53$, Pt. 2: Washington (U.S. Govt. Printing Office), 1169-1176.

Heaton, T. H. E., and Sheppard, S. M. F., 1977. Hydrogen and oxygen isotopic evidence for sea-water-hydrothermal alteration and ore deposition, Troodos complex, Cyprus. Volcanic Processes in Ore Genesis: London (Inst. Min. Met., Geol. Soc. Lond.), pp. 42-57.

Hey, R. N., 1975. Tectonic evolution of the Cocos-Nazca Rise [Ph. D. dissert.]. Princeton, N.J.

Hofmann, A. W., and Hart, S. R., 1978. An assessment of local and regional isotopic equilibrium in the mantle. Earth Planet. Sci. Lett., 38:44-62.

McCulloch, M. T., Gregor, R. T., Wasserburg, G. R., and Taylor, H. P., Jr., 1980. A neodymium, strontium, and oxygen isotopic study of the Cretaceous Samail ophiolite and implications for the petrogenesis and seawater-hydrothermal alteration of oceanic crust. Earth Planet. Sci. Lett., 46:201-211.

Mottl, M. J., and Holland, H. D., 1978. Chemical exchange during hydrothermal alteration of basalt by seawater-experimental results for major and minor components of seawater. Geochim. Cosmochim. Acta, 42:1103-1115.

Needham, H. D., and Francheteau, J., 1974. Some characteristics of the Rift Valley in the Atlantic Ocean near $36^{\circ} 48^{\prime}$ North. Earth Planet Sci. Lett., 22:29-43.

O'Nions, R. K., and Pankhurst, R. J., 1973. Determination of Rb/Sr and ${ }^{87} \mathrm{Sr} /{ }^{66} \mathrm{Sr}$ ratios of some standard rocks and evaluation of $\mathrm{X}$-ray fluorescence spectrometry in $\mathrm{Rb}-\mathrm{Sr}$ geochemistry. Chem. Geol., 12:127-136.

1974. Petrogenetic significance of isotope and trace element variations in volcanic rocks from the Mid-Atlantic. $J$. Petrol., 15:603-634.

1977. Sr-isotope and rare-earth element geochemistry of DSDP Leg 37 basalts. In Aumento, F., Melson, W. G., et al., Init. Repts. DSDP, 37: Washington (U.S. Govt. Printing Office), 599-601.

Peterman, Z. E., and Hedge, C. E., 1971. Related strontium isotopic and chemical variations in oceanic basalts. Geol. Soc. Am. Bull., 82:493-499.

Rea, D. K., 1977. Local axial migration and spreading rate variations, East Pacific Rise, $31^{\circ} \mathrm{S}$. Earth Planet. Sci. Lett., 34:78-84.

Richardson, S. H., Hart, S. R., and Staudigel, H., 1980. Vein mineral ages of old oceanic crust. J. Geophys. Res., 85:7195-7200.

Robertson, A. H. F., and Hudson, J. D., 1973. Cyprus umbers: chemical precipitates on a Tethyan ocean ridge. Earth Planet. Sci. Lett., 18:93-101.

Salisbury, M. H., Stephen, R., Christensen, N. I., Francheteau, J., Hamano, Y., Hobart, M., Johnson, D., 1980. The physical state of the upper levels of Cretaceous oceanic crust from the results of logging, laboratory studies and the oblique seismic experiment at Deep Sea Drilling Project Sites 417 and 418. In Donnelly, T., Francheteau, J., Bryan, W., Robinson, P., Flower, M., Salisbury, M., et al., Init. Repts. DSDP, 51, 52, 53, Pt. 2: Washington (U.S. Govt. Printing Office), 1579-1597.

Satake, H., and Matsuda, J., 1979. Strontium and hydrogen isotope geochemistry of fresh and metabasalt dredged from the MidAtlantic Ridge. Contr., Mineral. Petrol., 70:153-157.

Seyfried, W. E., Jr., and Bischoff, J. L., 1979. Low temperature basalt alteration by seawater: an experimental study at $70^{\circ} \mathrm{C}$ and $150^{\circ} \mathrm{C}$. Geochim. Cosmochim. Acta, 43:1937-1947.

Spooner, E. T. C., and Bray, C. J., 1977. Hydrothermal fluids of sea water salinity in ophiolitic sulphide ore deposits in Cyprus. $\mathrm{Na}$ ture, 266:808-812. 
Spooner, E. T. C., Chapman, M. H., and Smewing, J. D., 1977. Strontium isotopic contamination and oxidation during ocean floor hydrothermal metamorphism of the ophiolitic rocks of the Troodos massif, Cyprus. Geochim. Cosmochim. Acta, 41:873-890.

Staudigel, H., Frey, F. A., and Hart, S. R., 1980. Incompatible traceelement geochemistry and ${ }^{87 / 86} \mathrm{Sr}$ in basalts and corresponding glasses and palagonites. In Donnelly, T., Francheteau, J., Bryan, W., Robinson, P., Flower, M., Salisbury, M., et al., Init. Repts. DSDP, 51, 52, 53, Pt. 2: Washington (U.S. Govt. Printing Office), $1137-1144$.

Sun, S-S., Tatsumoto, M., and Schilling, J-G., 1975. Mantle plume mixing along the Reykjanes Ridge axis: lead isotope evidence. Science, 190:143-147.

Tatsumoto, M., 1966. Genetic relations of oceanic basalts as indicated by lead isotopes. Science, 153:1094-1101.

1978. Isotopic composition of lead in oceanic basalt and its implication to mantle evolution. Earth Planet. Sci. Lett., 38: 63-87.

Unruh, D. M., and Tatsumoto, M., 1976. Lead isotopic composition and uranium, thorium, and lead concentrations in sediments and basalts from the Nazca Plate. In Yeats, R. S., Hart, S. R., et al.,
Init. Repts. DSDP, 34: Washington (U.S. Govt. Printing Office), 341-347.

Veizer, J., and Compston, W., $1974 .{ }^{87} \mathrm{Sr} /{ }^{86} \mathrm{Sr}$ composition of seawater during the Phanerozoic. Geochim. Cosmochim. Acta, 38: 1461-1484.

White, W. H., and Schilling, J-G., 1978. The nature and origin of geochemical variation of Mid-Atlantic Ridge basalts from the central North Atlantic. Geochim. Cosmochim. Acta, 42:1501-1516.

Wolery, T. J., and Sleep, N. H., 1976. Hydrothermal circulation and geochemical flux at mid-ocean ridges. J. Geol., 84:249-275.

Wood, D. A., Joron, J-L., Treuil, M., Norry, M., and Tarney, J., 1979. Elemental and $\mathrm{Sr}$ isotope variations in basic lavas from Iceland and the surrounding ocean floor. Contr. Mineral. Petrol., 70:313-339.

Yamaguchi, M., Armstrong, R. L., Russell, R. D., and Slawson, W. F., 1977. Strontium and lead isotopic investigations of igneous rocks from the Mid-Atlantic Ridge: DSDP, Leg 37. In Aumento, F., and Melson, W. G., et al., Init. Repts. DSDP, 37: Washington (U.S. Govt. Printing Office), 613-616.

Yeats, R. S., Hart, S. R., et al., 1976. Init. Repts. DSDP, 34: Washington (U.S. Govt. Printing Office). 